\title{
Prevalence of elongated styloid process in Saudi population of Aseer region
}

\author{
Mohammed Asif Shaik ${ }^{1}$, Naheeda ${ }^{2}$, Sultan Mohammed Kaleem ${ }^{1}$, \\ Abdul Wahab ${ }^{3}$, Shahul Hameed ${ }^{1}$
}

Correspondence: Dr. Naheeda Email: dr.naheeda@gmail.com
'Department of Maxillofacial Diagnostic Sciences, College of Dentistry, King Khalid University, Abha, Kingdom of Saudi Arabia, 2Department of Periodontics, Mamatha Dental College, Khammam, Andhra Pradesh, India, ${ }^{3}$ Department of Preventive Dental Sciences, College of Dentistry, King Khalid University, Abha, Kingdom of Saudi Arabia

\section{ABSTRACT}

Objective: The study was performed to investigate the prevalence, morphology and calcification pattern of elongated styloid process in Saudi population of Aseer (Southern) region and its relation to gender and sub-age groups. Materials and Methods: This study was analyzed digital panoramic radiographs of 1,162 adults. Any radiograph with questionable styloid process was excluded from the study. The apparent length of the styloid process was measured by a single experienced dental and maxillofacial Radiologist. The elongated styloid process was classified with the radiographic appearance based on the morphology and calcification pattern. The data were analyzed by using Student's $t$-test and Chi-square test with $P$ value less than 0.05 . Results: A total of 1,085 Digital panoramic radiographs showed elongated styloid process of which $686(63.2 \%)$ were noticed in males and $399(36.8 \%)$ were noticed in female patients. There was a statistical significant difference noticed in the mean difference of elongated styloid process between 20-29, 50-59 and 60 years and above sub-age groups. The elongated styloid process was more prevalent in elderly aged male patients $(P<0.05)$. Type I morphology with calcified out line (a) was the most frequent pattern of calcification noticed in the present study. Conclusion: The panoramic radiographs are economical, easily accessible and useful diagnostic tool for early detection of elongated styloid process with or without symptoms. However, studies with larger sample size would further help to assess the prevalence of this elongated styloid process in Saudi population of various other regions.

Key words: Eagle's syndrome, panoramic radiographs, Saudi population, styloid process

\section{INTRODUCTION}

Styloid process is derived from the Greek word "Stylos" means a pillar, which is normally a cylindrical structure arising from the temporal bone anterior to stylomastoid foramen. ${ }^{[1]}$ The mean radiographic length of the styloid process is usually $2-3 \mathrm{~cm} \cdot{ }^{[2]}$ The apex of the styloid process is clinically important as it is located between internal and external carotid arteries. The tip of the styloid process is continuous with the stylohyoid ligament, which extends to the lesser cornu of the hyoid bone. ${ }^{[3]}$ The elongation of this styloid process or ossification of stylohyoid ligament can result in Eagle's syndrome. This was first described in 1652 by Italian surgeon Pietro Marchetti. In 1937, Eagle coined the term Stylalgia to describe the pain associated with elongation of the styloid process caused due to compression on some neural and vascular structures. ${ }^{[4]}$ It has been estimated that between $2 \%$ and $4 \%$ of the general population presents radiographic evidence of an ossified portion of the stylohyoid chain. Majority of these patients are asymptomatic. ${ }^{[5]}$ When symptoms do persist there is little correlation between the extent of the symptoms

\footnotetext{
How to cite this article: Shaik MA, N, Kaleem SM, Wahab A, Hameed S. Prevalence of elongated styloid process in Saudi population of Aseer region. Eur J Dent 2013;7:449-54.

Copyright $\odot 2013$ Dental Investigations Society. DOI: $10.4103 / 1305-7456.120687$
} 
and the severity of the ossification. More commonly, panoramic radiographs are used to determine the elongation of the styloid process. However, computed tomography is used as an adjunct for the information provided by panoramic radiographs. ${ }^{[5,6]}$ Langlais et al . proposed a classification on elongated styloid process based on the morphology of elongation [Figures 1-3]: Type I: Elongated, Type II: Pseudo articulated, Type III: Segmented and according to pattern of calcification [Figure 4]: (a) Calcified outline, (b) partially calcified, (c) nodular, (d) completely calcified. ${ }^{[7]}$ The aim of this study was to determine the prevalence of elongated styloid process in Saudi population of the southern region and to investigate the morphology and pattern of calcification of elongated styloid process in relation to gender and sub age groups with the help of digital panoramic radiograph.

\section{MATERIALS AND METHODS}

The study is based on 1,162 digital panoramic radiographs consecutively retrieved from the archival records. All radiographs were taken between 2009 and 2011 from Department Oral Medicine and Radiology College of Dentistry, King Khalid University, Abha, Saudi Arabia. The digital radiographs of 1,162 Saudi patients with dental problems had originally been taken for routine examination and not for the investigation. Hence, it was not necessary to seek ethical approval. All the panoramic radiographs were made by using Orthopantomograph ${ }^{\circledR}$ OP200D (Instrumentarium, Finland) operated at $85 \mathrm{kVp}$ and $2.5 \mathrm{~mA}$ with an exposure cycle of $10 \mathrm{~s}$ as recommended by the manufacturer. The radiographs with questionable stylohyoid complex, positioning and magnification errors and with superimposed normal anatomical structures were excluded from the study. The selected radiographs were of patient's above 10 years with the maximum age limit of 70 years. To obtain the percentiles for different age groups, the subjects were divided in to 10-19, 20-29, 30-39, 40-49, 50-59, and $\geq 60$ sub age groups. The apparent length of the styloid process was measured by an experienced oral and maxillofacial radiologist with the help of the measuring tools on the accompanying software (Clinic view 9.2, Instrumentarium) with a magnification factor of 1.4. The length of the styloid process was measured in a similar way described by Ilgüy et al.$^{[8]}$ Any styloid process extending below an imaginary line connecting the anterior nasal spine and the mastoid process was considered elongated. The type of the elongation and calcification of the styloid process on right and left side were evaluated according to Langlais et al. ${ }^{[7]}$ To check

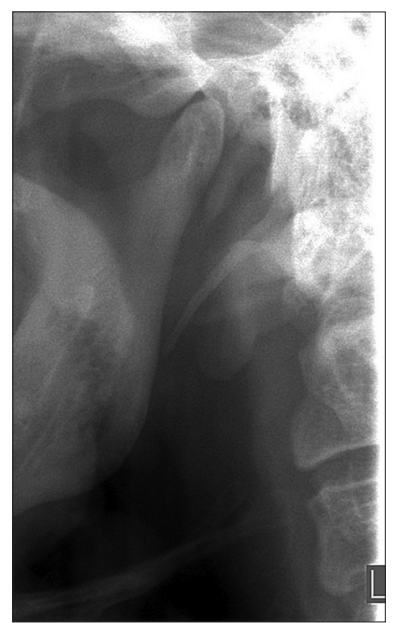

Figure 1: Type I: elongated styloid process

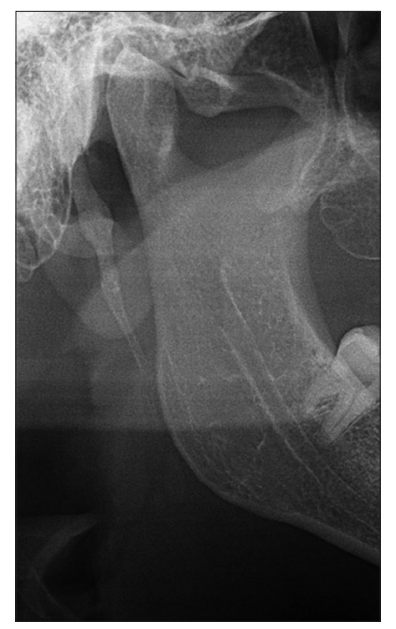

Figure 2: Type II: Pseudo articulated styloid process

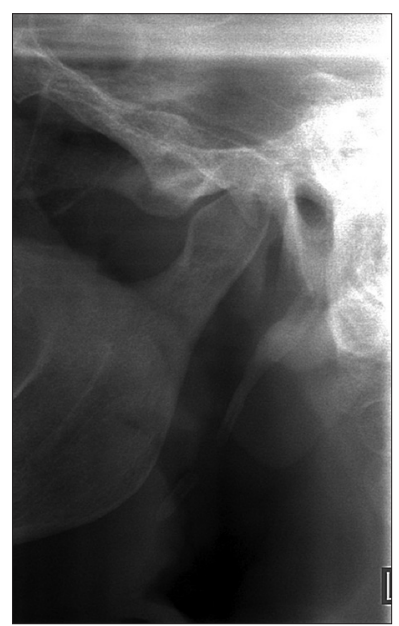

Figure 3: Type III: Segmented styloid process

the intraobserver variations, measurements were repeated after 1 month on a subset of 550 panoramic radiographs by the same observer. The deviation of the mean length of the styloid process between $1^{\text {st }}$ and 

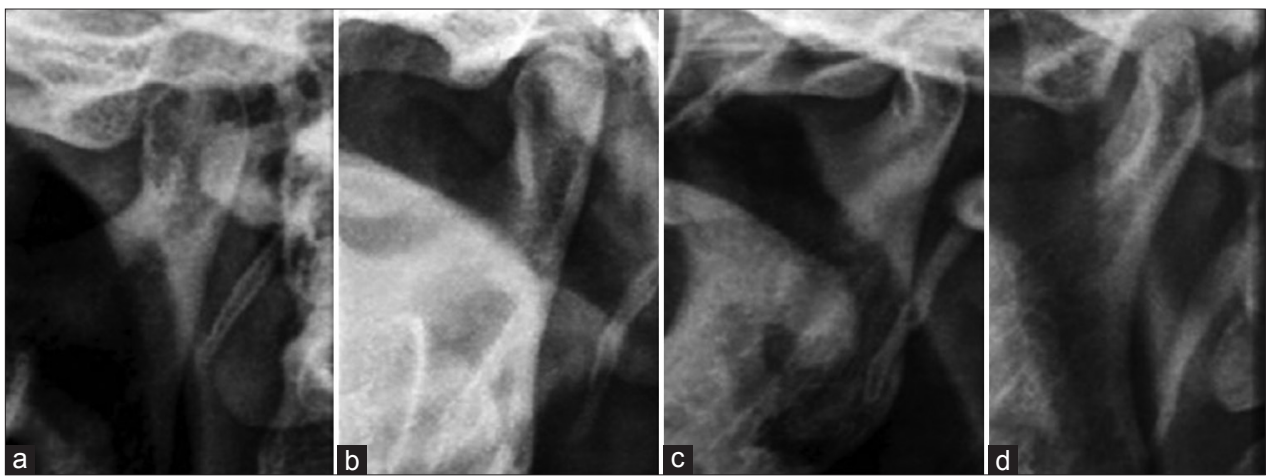

Figure 4: Calcification pattern of elongated styloid process

$2^{\text {nd }}$ measurements were $<2 \%$. The observed results were analyzed using SPSS 16.0 (statistical package for social science Inc. Chicago, USA) software. Student $t$-test and Chi-square test were used for statistical analysis. $P$ values less than 0.05 were accepted as statistically significant.

\section{RESULTS}

A total of 1,162 digital panoramic radiographs with dental problems were enrolled in the present study. The panoramic radiographs of 77 patients who have questionable styloid process were excluded. Therefore, 1,085 panoramic radiographs showed elongated styloid process of which, 686 (63.2\%) elongated styloid process were observed in males and 399 (36.8\%) were observed in females. Table 1 shows the mean difference of elongated styloid process between the gender, age and the side affected. The mean difference of elongated styloid process between the age group of 20-29, 50-59, and 60 years and above was more in males when compared to female patients, which was statistically significant $(P<0.05)$. Though, the mean difference of elongated styloid process was more in females between the age group of 40 and 49, it was not statistically significant. A statistical significant difference was noticed in the morphology of elongated styloid process in males [Table 2]. Type I morphology on the left side above 60 years of age was noticed in males. There was no significant difference noticed in the morphology of elongated styloid process in females. Calcified outline (a) [Table 3] was the most common calcified pattern noticed on right and left side of the male and right side of the female patients, which was statistically significant [Tables 4 and 5] shows the percentage distribution of morphology and calcified pattern of elongated styloid process in different sub age groups. Type I and calcified outline (a) were the most common morphology and calcified pattern in the specified sub age groups.

\begin{tabular}{|c|c|c|c|c|c|c|}
\hline \multirow[t]{2}{*}{ Age } & \multirow[t]{2}{*}{ ESPs } & \multicolumn{2}{|c|}{ Male } & \multicolumn{2}{|c|}{ Female } & \multirow[t]{2}{*}{$P$ value } \\
\hline & & Mean & SD & Mean & SD & \\
\hline \multirow[t]{2}{*}{$10-19$} & Right side & 33 & 1.98 & 32.8 & 1.20 & 0.599 \\
\hline & Left side & 33.2 & 1.89 & 33.1 & 1.06 & 1.35 \\
\hline \multirow[t]{2}{*}{$20-29$} & Right side & 34.2 & 2.23 & 33.5 & 1.89 & $0.029^{*}$ \\
\hline & Left side & 34.5 & 2.01 & 33.8 & 1.44 & $0.003^{*}$ \\
\hline \multirow[t]{2}{*}{$30-39$} & Right side & 34.6 & 2.56 & 34.3 & 2.02 & 0.27 \\
\hline & Left side & 34.7 & 2.07 & 34.2 & 2.09 & 0.148 \\
\hline \multirow[t]{2}{*}{$40-49$} & Right side & 35.4 & 2.42 & 35.8 & 2.51 & 0.325 \\
\hline & Left side & 35.7 & 2.48 & 36.4 & 2.22 & 0.100 \\
\hline \multirow[t]{2}{*}{$50-59$} & Right side & 36.0 & 2.42 & 35.5 & 2.44 & $0.0031^{*}$ \\
\hline & Left side & 36.6 & 2.42 & 35.6 & 2.67 & $0.0037^{*}$ \\
\hline \multirow[t]{2}{*}{$\geq 60$} & Right side & 36.1 & 2.34 & 35.6 & 2.51 & $0.0039^{*}$ \\
\hline & Left side & 36.7 & 2.47 & 35.2 & 2.61 & $0.0035^{*}$ \\
\hline
\end{tabular}

\section{DISCUSSION}

The styloid process and ligaments are derived from the $1^{\text {st }}$ and $2^{\text {nd }}$ brachial arches, in addition to Reichert's cartilage. It has been demonstrated that during fetal development Reichert's cartilage links the styloid bone to the hyoid bone. In the adult, the stylohyoid ligament may retain some of its embryonic cartilage and may become partially or completely ossified. If these structures solidify they can cause pain and suffering present in symptomatic cases. The actual cause of elongation is poorly understood several theories have been proposed. It could be due to growth of osseous tissue at the insertion of stylohyoid ligament or it could be due to calcification of stylohyoid ligament due to unknown process or due to persistence of cartilaginous analog of stylohyal. ${ }^{[9,10]}$ There has always been a natural variation in the length of the styloid process as debated by various researchers. It has been previously reported that the normal radiographic length of the styloid process is $2-3 \mathrm{~mm}$ of which, the pathogenic importance is the spatial 


\begin{tabular}{|c|c|c|c|c|c|c|c|c|c|c|c|c|c|c|c|}
\hline \multirow[t]{3}{*}{ Gender } & \multirow[t]{3}{*}{ Age } & \multicolumn{6}{|c|}{ Gender age morphology on right side } & \multirow[t]{3}{*}{$P$ value } & \multicolumn{6}{|c|}{ Morphology on left side } & \multirow[t]{3}{*}{$P$ value } \\
\hline & & \multicolumn{2}{|c|}{ Type I } & \multicolumn{2}{|c|}{ Type II } & \multicolumn{2}{|c|}{ Type III } & & \multicolumn{2}{|c|}{ Type I } & \multicolumn{2}{|c|}{ Type II } & \multicolumn{2}{|c|}{ Type III } & \\
\hline & & $n$ & $\%$ & $n$ & $\%$ & $n$ & $\%$ & & $n$ & $\%$ & $n$ & $\%$ & $n$ & $\%$ & \\
\hline \multirow[t]{6}{*}{ Female } & $10-19$ & 17 & 8.7 & 8 & 6.0 & 2 & 2.9 & 0.625 & 19 & 10.0 & 7 & 5.2 & 1 & 1.4 & 0.343 \\
\hline & $20-29$ & 37 & 19 & 28 & 21.1 & 12 & 17.1 & & 36 & 18.9 & 25 & 18.2 & 16 & 22 & \\
\hline & $30-39$ & 31 & 15.8 & 14 & 10.5 & 14 & 20.0 & & 31 & 16.3 & 21 & 15.3 & 7 & 9.7 & \\
\hline & $40-49$ & 26 & 13.3 & 16 & 12.0 & 10 & 14.3 & & 23 & 12.2 & 17 & 12.4 & 12 & 16.7 & \\
\hline & $50-59$ & 37 & 19 & 28 & 21.1 & 11 & 15.7 & & 36 & 18.9 & 25 & 18.2 & 15 & 20.8 & \\
\hline & $\geq 60$ & 48 & 24.2 & 39 & 29.3 & 21 & 30.0 & & 45 & 23.7 & 42 & 30.7 & 21 & 29.4 & \\
\hline \multirow[t]{6}{*}{ Male } & $10-19$ & 32 & 10.1 & 17 & 5.9 & 1 & 1.4 & $<0.001^{*}$ & 36 & 9.8 & 14 & 6.2 & 0 & 0 & $<0.001^{*}$ \\
\hline & $20-29$ & 66 & 20.8 & 35 & 11.9 & 10 & 13.3 & & 72 & 19.5 & 31 & 13.5 & 8 & 9.1 & \\
\hline & $30-39$ & 52 & 16.4 & 53 & 18.0 & 10 & 13.3 & & 64 & 17.3 & 28 & 12.2 & 23 & 26.1 & \\
\hline & $40-49$ & 50 & 15.8 & 56 & 19.0 & 20 & 26.7 & & 49 & 13.3 & 53 & 23.1 & 24 & 27.3 & \\
\hline & $50-59$ & 46 & 14.5 & 75 & 25.5 & 18 & 24.0 & & 64 & 17.3 & 56 & 24.5 & 19 & 21.6 & \\
\hline & $\geq 60$ & 71 & 22.4 & 58 & 19.7 & 16 & 21.3 & & 84 & 22.8 & 47 & 20.5 & 14 & 15.9 & \\
\hline
\end{tabular}

\begin{tabular}{|c|c|c|c|c|c|c|c|c|c|c|c|c|c|c|c|c|c|c|c|}
\hline \multirow[t]{3}{*}{ Gender } & \multirow[t]{3}{*}{ Age } & \multicolumn{8}{|c|}{ Calcification on right side } & \multirow[t]{3}{*}{$P$ value } & \multicolumn{8}{|c|}{ Calcification on left side } & \multirow[t]{3}{*}{$P$ value } \\
\hline & & \multicolumn{2}{|c|}{ A } & \multicolumn{2}{|c|}{ B } & \multicolumn{2}{|c|}{ C } & \multicolumn{2}{|c|}{ D } & & \multicolumn{2}{|c|}{ A } & \multicolumn{2}{|c|}{ B } & \multicolumn{2}{|c|}{ C } & \multicolumn{2}{|c|}{ D } & \\
\hline & & $n$ & $\%$ & $n$ & $\%$ & $n$ & $\%$ & $n$ & $\%$ & & $n$ & $\%$ & $n$ & $\%$ & $n$ & $\%$ & $n$ & $\%$ & \\
\hline \multirow[t]{6}{*}{ Female } & $10-19$ & 22 & 9.4 & 5 & 3.8 & 0 & 0 & 0 & 0 & $0.043^{*}$ & 20 & 12.2 & 3 & 2.9 & 0 & 0 & 4 & 3.9 & 0.106 \\
\hline & $20-29$ & 51 & 21.9 & 19 & 14.3 & 2 & 25 & 5 & 20 & & 28 & 17.1 & 25 & 24 & 5 & 18 & 19 & 18.4 & \\
\hline & $30-39$ & 33 & 14.2 & 19 & 14.3 & 0 & 0 & 7 & 28 & & 29 & 17.7 & 11 & 10.6 & 6 & 21.4 & 13 & 12.6 & \\
\hline & $40-49$ & 25 & 10.7 & 24 & 18.0 & 1 & 12.5 & 2 & 8.0 & & 19 & 11.6 & 11 & 10.6 & 5 & 17.9 & 17 & 16.5 & \\
\hline & $50-59$ & 50 & 21.5 & 19 & 14.3 & 2 & 25.0 & 5 & 20 & & 28 & 17.1 & 24 & 23.1 & 5 & 17.9 & 19 & 18.4 & \\
\hline & $\geq 60$ & 52 & 22.3 & 47 & 35.3 & 3 & 37.5 & 6 & 24 & & 40 & 24.4 & 30 & 28.8 & 7 & 25.0 & 31 & 30.1 & \\
\hline \multirow[t]{6}{*}{ Male } & $10-19$ & 47 & 11.6 & 2 & 1.2 & 1 & 3.8 & 0 & 0 & $<0.001^{*}$ & 40 & 13.6 & 7 & 3.7 & 1 & 1.6 & 2 & 1.4 & $<0.001^{*}$ \\
\hline & $20-29$ & 91 & 22.5 & 18 & 10.5 & 1 & 3.8 & 1 & 1.2 & & 63 & 21.4 & 34 & 17.9 & 2 & 3.3 & 12 & 8.5 & \\
\hline & $30-39$ & 77 & 19.0 & 34 & 19.9 & 0 & 0 & 4 & 4.8 & & 42 & 14.3 & 20 & 10.5 & 24 & 39.3 & 29 & 20.6 & \\
\hline & $40-49$ & 36 & 8.9 & 63 & 36.8 & 17 & 65.4 & 10 & 11.9 & & 45 & 15.3 & 22 & 11.6 & 0 & 0 & 59 & 41.8 & \\
\hline & $50-59$ & 60 & 14.8 & 22 & 12.9 & 4 & 15.4 & 53 & 63.1 & & 34 & 11.6 & 67 & 35.3 & 27 & 44.3 & 11 & 7.8 & \\
\hline & $\geq 60$ & 94 & 23.2 & 32 & 18.7 & 3 & 11.5 & 16 & 19.0 & & 70 & 23.8 & 40 & 21.1 & 7 & 11.5 & 28 & 19.9 & \\
\hline
\end{tabular}

\begin{tabular}{|c|c|c|c|c|c|c|c|c|c|c|c|c|c|}
\hline \multirow[t]{3}{*}{ Age } & \multirow[t]{3}{*}{ Gender } & \multicolumn{6}{|c|}{ Morphology on right side } & \multicolumn{6}{|c|}{ Morphology on left side } \\
\hline & & \multicolumn{2}{|c|}{ Type I } & \multicolumn{2}{|c|}{ Type II } & \multicolumn{2}{|c|}{ Type III } & \multicolumn{2}{|c|}{ Type I } & \multicolumn{2}{|c|}{ Type II } & \multicolumn{2}{|c|}{ Type III } \\
\hline & & $n$ & $\%$ & $n$ & $\%$ & $n$ & $\%$ & $n$ & $\%$ & $n$ & $\%$ & $n$ & $\%$ \\
\hline \multirow[t]{2}{*}{$10-19$} & Female & 17 & 63 & 8 & 29.6 & 2 & 7.4 & 19 & 70.4 & 7 & 25.9 & 1 & 3.7 \\
\hline & Male & 32 & 64 & 17 & 34.0 & 1 & 2.0 & 36 & 72.0 & 14 & 28.0 & 0 & 0 \\
\hline \multirow[t]{2}{*}{$20-29$} & Female & 37 & 48.1 & 28 & 36.4 & 12 & 15.6 & 36 & 46.8 & 25 & 32.5 & 16 & 20.8 \\
\hline & Male & 66 & 59.5 & 35 & 31.5 & 10 & 9.0 & 72 & 64.9 & 31 & 27.9 & 8 & 7.2 \\
\hline \multirow[t]{2}{*}{$30-39$} & Female & 31 & 52.5 & 14 & 23.7 & 14 & 23.7 & 31 & 52.5 & 21 & 35.6 & 7 & 11.9 \\
\hline & Male & 52 & 45.2 & 53 & 46.1 & 10 & 8.7 & 64 & 55.7 & 28 & 24.3 & 23 & 20.0 \\
\hline \multirow[t]{2}{*}{$40-49$} & Female & 26 & 50.0 & 16 & 30.8 & 10 & 19.2 & 23 & 44.2 & 17 & 32.7 & 12 & 23.1 \\
\hline & Male & 50 & 39.7 & 56 & 44.4 & 20 & 15.9 & 49 & 38.9 & 53 & 42.1 & 24 & 19.0 \\
\hline \multirow[t]{2}{*}{$50-59$} & Female & 37 & 48.7 & 28 & 36.8 & 11 & 14.5 & 36 & 47.4 & 25 & 32.9 & 15 & 19.7 \\
\hline & Male & 46 & 33.1 & 75 & 54.0 & 18 & 12.9 & 64 & 46.0 & 56 & 40.3 & 19 & 13.7 \\
\hline \multirow[t]{2}{*}{$\geq 60$} & Female & 45 & 41.7 & 42 & 38.9 & 21 & 19.4 & 45 & 41.7 & 42 & 38.9 & 21 & 19.4 \\
\hline & Male & 71 & 49.0 & 58 & 40.0 & 16 & 11.0 & 84 & 57.9 & 47 & 32.4 & 14 & 9.7 \\
\hline
\end{tabular}

position of the tip of this process. ${ }^{[10]}$ Kaufman et al. ${ }^{[11]}$ states that, if the length of the styloid process is more than $30 \mathrm{~mm}$ on the radiograph it is considered as elongated. In the present study, the styloid process, 
Shaik, et al.: Prevalence of elongated styloid process

\begin{tabular}{|c|c|c|c|c|c|c|c|c|c|c|c|c|c|c|c|c|c|}
\hline \multirow[t]{3}{*}{ Age } & \multirow[t]{3}{*}{ Gender } & \multicolumn{8}{|c|}{ Calcification on right } & \multicolumn{8}{|c|}{ Calcification on left side } \\
\hline & & \multicolumn{2}{|c|}{ A } & \multicolumn{2}{|c|}{ B } & \multicolumn{2}{|c|}{ C } & \multicolumn{2}{|c|}{ D } & \multicolumn{2}{|c|}{ A } & \multicolumn{2}{|c|}{ B } & \multicolumn{2}{|c|}{ C } & \multicolumn{2}{|c|}{ D } \\
\hline & & $n$ & $\%$ & $n$ & $\%$ & $n$ & $\%$ & $n$ & $\%$ & $n$ & $\%$ & $n$ & $\%$ & $n$ & $\%$ & $n$ & $\%$ \\
\hline \multirow[t]{2}{*}{$10-19$} & Female & 22 & 81.5 & 5 & 18.5 & 0 & 0 & 0 & 0 & 20 & 74.1 & 3 & 11.1 & 0 & 0 & 4 & 14.8 \\
\hline & Male & 47 & 94 & 2 & 4.0 & 1 & 2 & 0 & 0 & 40 & 80.0 & 7 & 14.0 & 1 & 2 & 2 & 4.0 \\
\hline \multirow[t]{2}{*}{$20-29$} & Female & 51 & 66.2 & 19 & 24.7 & 2 & 2.6 & 5 & 6.5 & 28 & 36.4 & 25 & 32.5 & 5 & 6.5 & 19 & 24.7 \\
\hline & Male & 91 & 82.0 & 18 & 16.2 & 1 & 0.9 & 1 & 0.9 & 63 & 56.8 & 34 & 30.6 & 2 & 1.8 & 12 & 10.8 \\
\hline \multirow[t]{2}{*}{$30-39$} & Female & 33 & 55.9 & 19 & 32.2 & 0 & 0 & 7 & 11.9 & 29 & 49.2 & 11 & 18.6 & 6 & 10.2 & 13 & 22.0 \\
\hline & Male & 77 & 67.0 & 34 & 29.6 & 0 & 0 & 4 & 3.5 & 42 & 36.5 & 20 & 17.4 & 24 & 20.9 & 29 & 25.2 \\
\hline \multirow[t]{2}{*}{$40-49$} & Female & 25 & 48.1 & 24 & 46.2 & 1 & 1.9 & 2 & 3.8 & 19 & 36.5 & 11 & 21.2 & 5 & 9.6 & 17 & 32.7 \\
\hline & Male & 36 & 28.6 & 63 & 50.0 & 17 & 13.5 & 10 & 7.9 & 45 & 35.7 & 22 & 17.5 & 0 & 0 & 59 & 46.8 \\
\hline \multirow[t]{2}{*}{$50-59$} & Female & 50 & 65.8 & 19 & 25.0 & 2 & 2.6 & 5 & 6.6 & 28 & 36.8 & 24 & 31.6 & 5 & 6.6 & 19 & 25.0 \\
\hline & Male & 60 & 43.2 & 22 & 15.8 & 4 & 2.9 & 53 & 38.1 & 34 & 24.5 & 67 & 48.2 & 27 & 19.4 & 11 & 7.9 \\
\hline \multirow[t]{2}{*}{$\geq 60$} & Female & 52 & 48.1 & 47 & 43.5 & 3 & 2.8 & 6 & 5.6 & 40 & 37.0 & 30 & 27.8 & 7 & 6.5 & 31 & 28.7 \\
\hline & Male & 94 & 64.8 & 32 & 22.1 & 3 & 2.1 & 16 & 11.0 & 70 & 48.3 & 40 & 27.6 & 7 & 4.8 & 28 & 19.3 \\
\hline
\end{tabular}

which were longer than $30 \mathrm{~mm}$ were included for evaluation. There are many variations of styloid chain, including the thickness of segments, angle and direction of deviation, length of process and degree of calcification. ${ }^{[12]}$ Therefore, it is necessary to define the type of elongation and calcification of each styloid in order to describe its radiographic appearance. Hence, in order to simplify the description, Langlais et al. ${ }^{[7]}$ had classified styloid process based on the type of elongation and calcification. Similar classification was followed in the present study to describe the morphology and calcification of the styloid process. The panoramic radiograph rather than computed tomography are used to detect if the styloid process is elongated. ${ }^{[13]}$ Similarly, in the present study panoramic radiographs were used to identify the elongated styloid process. The average length of the styloid process was $3.67 \pm 0.62 \mathrm{~cm}$ with a mean age of elongation was $42.95 \pm 16.62$ in males and $37.6 \pm 14.2$ in female patients. There was a significant difference in the mean elongation of the styloid process between the age group of 20-29, $50-59$, and above 60 years of age. These findings were in consistent with the study conducted by Gokce et al. in Turkey population. ${ }^{[14]}$ In the present study, it was observed that there was an increase in the length of the styloid process with an increase in the age. These findings were in consistent with studies conducted by various authors. ${ }^{[15,16]}$ It was also observed that the styloid processes were elongated more in males when compared to females and more on the left side when compared to right side. However, these findings were not in consistent with studies conducted by various authors. ${ }^{[15-17]}$ Type I morphology was the most common type of morphology observed in male patients. However, it was not statistically significant in females. The calcified outline (a) was the common calcified pattern was seen in males and on the right side of female patients. Similar findings were noticed by Ilgüy et al. in term of most common type of elongated styloid process. However, they found the partial calcification to be the most prevalent pattern. Similarly, Reddy et al..$^{[18]}$ and Bagga et al. ${ }^{[19]}$ reported similar results in term of most common type of styloid process. However, they found completely calcified and partially calcified pattern most prevalent in south and north Indian population. The percentage distribution of elongated styloid process in different sub age group showed Type I (33.1-72\%) as the most common type of elongation and calcified outline (28.6-94\%) as the most common pattern of calcification in the specified subgroups of Saudi population.

\section{CONCLUSION}

It is important for the dentist to be aware of natural variations of the styloid process whose clinical importance is not well-understood. Styloid process elongation may often be a coincidental asymptomatic radiographic finding. Therefore, proper clinical and radiographic evaluation can detect an elongated styloid process. The panoramic radiographs are economical, easily access able and useful diagnostic aid for early detection of elongated styloid process with or without symptoms. To the best of our knowledge, this is the first of it kind of study in terms of the prevalence of elongated styloid process in Saudi population of Aseer region. However, studies with larger sample size would further help to assess the prevalence of this elongated styloid process in Saudi population of various other regions. 


\section{REFERENCES}

1. Roopashri G, Vaishali MR, David MP, Baig M. Evaluation of elongated styloid process on digital panoramic radiographs. J Contemp Dent Pract 2012;13:618-22.

2. Bozkir MG, Boga H, Dere F. The evaluation of styloid process in panoramic radiographs in edentulous patients. Turk J Med Sci 1999:29:481-5.

3. Frommer J. Anatomic variations in the stylohyoid chain and their possible clinical significance. Oral Surg Oral Med Oral Pathol 1974;38:659-67.

4. Eagle WW. Symptomatic elongated styloid process; report of two cases of styloid process-carotid artery syndrome with operation. Arch Otolaryngol 1949;49:490-503.

5. Prasad KC, Kamath MP, Reddy KJ, Raju K, Agarwal S. Elongated styloid process (Eagle's syndrome): A clinical study. J Oral Maxillofac Surg 2002;60:171-5.

6. Jaju PP, Suvarna P, Parikh N. Eagles syndrome: An enigma to dentists. J Indian Acad Oral Med Radiol 2007;19:424-9.

7. Langlais RP, Miles DA, Van Dis ML. Elongated and mineralized stylohyoid ligament complex: A proposed classification and report of a case of Eagle's syndrome. Oral Surg Oral Med Oral Pathol 1986;61:527-32.

8. Ilgüy M, Ilgüy D, Güler N, Bayirli G. Incidence of the type and calcification patterns in patients with elongated styloid process. J Int Med Res 2005;33:96-102.

9. Joshi V, Iyengar AR, Nagesh KS, Gupta J. Elongated styloid process: A radiographic study. J Indian Acad Oral Med Radiol 2007;19:498-502.

10. Okabe S, Morimoto Y, Ansai T, Yamada K, Tanaka T, Awano S, et al . Clinical significance and variation of the advanced calcified stylohyoid complex detected by panoramic radiographs among 80-year-old subjects. Dentomaxillofac Radiol 2006;35:191-9.
11. Kaufman SM, Elzay RP, Irish EF. Styloid process variation. Radiologic and clinical study. Arch Otolaryngol 1970;91:460-3.

12. More $\mathrm{CB}$, Asrani MK. Evaluation of the styloid process on digital panoramic radiographs. Indian J Radiol Imaging 2010;20:261-5.

13. Keur JJ, Campbell JP, McCarthy JF, Ralph WJ. The clinical significance of the elongated styloid process. Oral Surg Oral Med Oral Pathol 1986;61:399-404.

14. Gokce C, Sisman Y, Ertas ET, Akgunlu F, Ozturk A. Prevalence of styloid process elongation on panoramic radiography in the Turkey population from Cappadocia region. Eur J Dent 2008;2:18-22.

15. Scaf G, Freitas DQ, Loffredo Lde C. Diagnostic reproducibility of the elongated styloid process. J Appl Oral Sci 2003;11:120-4.

16. Shah SP, Praveen NB, Syed V, Subhashini AR. Elongated styloid process: A retrospective panoramic radiograph study. World J Dent 2012;3:316-9.

17. Balcioglu HA, Kilic C, Akyol M, Ozan H, Kokten G. Length of the styloid process and anatomical implications for Eagle's syndrome. Folia Morphol (Warsz) 2009;68:265-70.

18. Reddy RS, Kiran CH, Madhavi NS, Raghavendra MN, Satish A Prevalence of elongation and calcification patterns of elongated styloid process in South India. J Clin Exp Dent 2013;5:30-5.

19. Bagga MB, Kumar CA, Yeluri G. Clinicoradiologic evaluation of styloid process calcification. Imaging Sci Dent 2012;42:155-61.

\begin{tabular}{|l|l|}
\hline \multicolumn{2}{|c|}{ Access this article online } \\
\hline Quick Response Code: & Website: \\
& www.eurjdent.com \\
& Source of Support: Nil. \\
& Conflict of Interest: None declared
\end{tabular}

Announcement

Android App

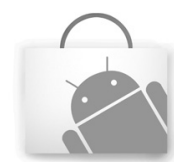

Download Android application
A free application to browse and search the journal's content is now available for Android based mobiles and devices. The application provides "Table of Contents" of the latest issues, which are stored on the device for future offline browsing. Internet connection is required to access the back issues and search facility. The application is compatible with all the versions of Android. The application can be downloaded from https://market.android.com/details?id=comm.app.medknow. For suggestions and comments do write back to us. 